Pp.173-190

\title{
Teaching Translation through the Implementation of Expressive Utterances Translation Technique in Disney's Aladdin Movie 2019
}

\author{
Farrah Zakiyah Anwar
}

Department of English Education, Muhammadiyah University of Surakarta, Surakarta, Indonesia

\section{Dwi Haryanti}

Department of English Education, Muhammadiyah University of Surakarta, Surakarta, Indonesia

\section{Muhammad Thoyibi}

Department of English Education, Muhammadiyah University of Surakarta, Surakarta, Indonesia

\begin{abstract}
:
Communication's purpose is delivered when the intention of the speaker or writer is accepted and understood by the readers and listeners. People have their way of delivering ideas explicitly or implicitly in the communication process. Therefore, comprehending techniques of translation becomes influential in building meaningful connections and enhance students' competence in the translation. However, students believe that translation is tiring and boring, which makes the students' ability in translation low. The research aims are to analyze translation techniques in Disney's Aladdin (2019) focused on the use of expressive utterances and how to implement the techniques in teaching translation. Through a descriptive qualitative method, the writers analyzed the data by selecting, identifying, classifying, describing the data, and from the results, draw conclusions. The data were analyzed by using Searle's (1969) speech act theory. The results showed that there are seven kinds of expressive utterances translation techniques used in Disney's Aladdin (2019), such as linguistics compression, established equivalence, literal translation, reduction, amplification, modulation, and calque. Implementing translation techniques in teaching translation can increase sensitivity into language, gain more extensive insights about cultures, and enable in producing better translation quality. Furthermore, teaching translation techniques becomes significant in developing students' critical thinking to present ideas into target language appropriately. This research will give information concerning the use of translation techniques and how to apply them in translation teaching. Further research can replace the media for translation techniques learning.

Keywords: expressive speech act, disney's aladdin movie 2019, translation, translation teaching, translation techniques

Cite as: Anwar, F. Z. , Haryanti, D. , \& Thoyibi, M. (2020). Teaching Translation through the Implementation of Expressive Utterances Translation Technique in Disney's Aladdin Movie 2019. Arab World English Journal for Translation \& Literary Studies 4 (3) 173-190.
\end{abstract}

DOI: http://dx.doi.org/10.24093/awejtls/vol4no3.14

Arab World English Journal for Translation \& Literary Studies 
AWEJ for Translation \& Literary Studies Volume, 4 Number 3 August 2020

Teaching Translation through the Implementation of Expressive

Anwar, Haryanti \& Thoyibi

\section{Introduction}

Communication becomes a need for every human being to interact and establish relationships as social beings. By communicating, people can exchange information in the form of messages, ideas, and opinions. Communication occurring between humans is built by the existence of language as a medium to express ideas and convey messages explicitly and implicitly (Williams, 1977). With globalization, humans are inseparable from the emergence and exposure of foreign languages. English becomes the most used foreign language all around the globe (Muntane \& Faraco, 2016). Most sources of knowledge, such as books, journals, and news, commonly use English in providing information, in which English has an essential role in expanding knowledge and information. Besides, many literary works, including films, novels, dramas, and poems, also use English to convey their messages. Therefore, it is crucial to learn and understand the language to grasp its precise meaning, in which translation becomes significant in its process.

Translating does not only mean changing specific language, but one must also consider the acceptability of meaning. According to Catford (1978) and Pinchuck (1977), translation is the process of changing the content of discourse from one language to another by paying attention to the exact equivalent of the word. Meanwhile, according to Newmark (1988), translation is an activity of transferring messages from its source language into the target language without any change in meaning. It means that translation is not only related to the evolution of one style to another style but also retain the conveyed meaning as intended by the author; therefore, the reader would be able to understand the meaning of a text with the correct understanding. However, the translation process is not an easy job as people do encounter several problems during their operation. Wuryantoro (2017) found a problem in the translation process, such: linguistic elements containing the change of grammatical structures and lexical meaning, as well as other aspects of linguistics, namely the additional fields and cultural competence.

Language and cultural aspects cannot be separated from the translation process because language is part of a culture. In everyday life, through words, deeds, behavior, and habits are the reflection of culture. Therefore, during translation, translators must also consider the cultural aspects because the culture depicted in the source language might not be similar to the target language. This is in line with Bai (2018) that translation is an exchange of cultural information from both languages. Moreover, to translate the intended results, one must also master the comprehension of two languages.

In addition to comprehending cultural aspects, translation techniques also have a significant role in producing quality translation products. Translators cannot provide accurate translations if they do not have a good understanding of both languages and mastery of translation techniques. Therefore, the application of translation techniques is a practical way for translators to overcome the difficulty of finding accurate words. Catford (1978) considered the most straightforward technique is a literal translation technique. However, translating sentences or utterances cannot be done only by applying literal techniques. Every uttered speech act has a different style; therefore, mastering several translation techniques is a must for translators to convey the intended meaning naturally. As stated by Nida and Taber (1974), translation aim is to 
define a language style that is naturally comparable based on the source language, which then transferred to its target language.

The comprehension of several translation techniques becomes vital not only for an experienced translator but also for translation students. Translation techniques will be useful for students in understanding teaching materials. However, using conventional learning materials will make students bored and tired, so that students' abilities do not improve. From various teaching materials available, the film is the most popular entertainment media and has a positive influence to increase motivation in learning foreign languages, because the film can present a real picture by the cultural context (Kusumarasdyati, 2004; Luo, 2004; Sommer, 2001). Besides, applying film as a medium for learning foreign languages can increase students' sensitivity in understanding languages. By knowing translation techniques, these students will be able to produce accurate translation products.

Therefore, this research aims to:

1. analyze translation techniques used by translators to translate expressive speech acts found in Disney's Aladdin (2019).

2. discover the methods to apply translation techniques in teaching translation.

The results of the present research are expected to provide knowledge related to translation techniques application and how to apply them in translation teaching.

\section{Literature Review Translation}

There are several definitions of translation expressed by experts. Warwal (2015) asserted that "different author give different types of the process of translation but the main propose of translations to translate the S.L.T into T.L.T, in this process the first step is decoding the S.L test, the another, first of all understands about the inherent port of the source language text" (p. 125). According to Catford's (1978) and Warwal's (2015) definition, that is an effort to maintain the meaning of the language from the source language into the target language to convey the message accurately. Larson (1984) pointed out, when the translation occurred, changing the form of language could be accepted as long as the intended message did not change. Both definitions emphasized that the translation process refers to the importance of retaining the message from source language to its target language despite the change of language structure (Bassnett-McGuire, 1980).

Hartono (2012) added that the process of producing meaning from reading activities in the native language is called translation. Based on Newmark (1989), translation is inseparable from art, which also means that translation is not merely a transfer of language but also an art of conveying a message in a way it can be acceptable in the target language. Owing to this, Warwal (2015) confirmed that the process of communicating the meaning of the original language into the target language which produces a comparable message.

Arab World English Journal for Translation \& Literary Studies 
Therefore, translation does not only occur in the written word but also spoken word. To be able to translate language well and create natural translation products, translators must understand the patterns of both communications so that they can produce meaning and style of language that is commensurate with the target language (Nida \& Taber, 1974). Also, Bai (2018) emphasized that "the definition of culture is needful for translators" (p.121). Since, "translation is not only a translation between two languages, but also a kind of cross-cultural communication" (Tereva in Yakup, 2016, p. 54).

As explained by experts, translation is challenging because translators must maintain the author's message to retain the intended meaning and convey it properly. Besides, the competence of culture and experience is needed to be able to produce a good quality translation that can be understood by its target readers even though presented in a different form.

\section{Translation Techniques}

The successful translation occurs, if the translated product delivers meaning corresponding to the linguistic aspects of the target language based on the prevailing cultural context as described by Halliday in Steiner (2004). Besides, translation is done by understanding the components of language, grammatical structure, cultural situation, and meaning of the source language, which then transferred and adjusted to the linguistic and extra-linguistic aspects that will apply in the target language. Furthermore, all information contained in the original language must include both lexical and grammatical meanings, cultural conditions, and cultural norms. In other words, translation examines the elements of the lexicon, grammatical structure, communication situation, and cultural contact between two languages, which are carried out through analysis to determine the meaning.

To afford quality product in translation, it is influential to understand and master translation techniques (Akhiroh , 2013; Aresta, Nababan \& Djatmika, 2018). Since, "the use of precise techniques will produce a high quality of translation product” (Agustino, 2011, p.5).

Molina and Albir (2002) described several translation techniques to solve difficulties in the translation process. They are:

1. Adaptation; is a translation technique for finding cultural equivalents between two specific situations. The translator uses this technique when the cultural elements in the source language not found in the target language, so the translator must create a condition that equal to the culture inherent in the target language.

2. Amplification; this technique refers to adding information to the target language that aims to facilitate the reader in understanding the meaning.

3. Borrowing; is a technique that borrows lexical elements such as words or expressions from the source language into the target language. There are two types of borrowing, they are pure borrowing (without modification), and naturalized borrowing (with adjustment).

4. Calque; translation based on the meaning of the word and its structure. The transfer of language from the original text into the target language takes place literally. 
AWEJ for Translation \& Literary Studies Volume, 4 Number 3 August 2020

Teaching Translation through the Implementation of Expressive

Anwar, Haryanti \& Thoyibi

5. Linguistics compensation; is a reduction of linguistic elements in translation products to shorten speech. The application of this technique is usually in dubbing and interpreting.

6. Description; is a technique that provides additional functions and explanations related to terms in the source language so that the reader can receive the message properly.

7. Discursive creation; this technique used to translate a title of work that uses another perspective and the results of translation in the target language can get off from the context contained in the source language.

8. Established equivalent; this translation technique is done by finding equivalent words, and terms commonly used in the target language.

9. Generalization; is a translation technique to translate words or special terms in the source language into general terms in the target language.

10. Linguistic amplification; this technique adds the usual linguistic elements to the translation product, and the addition is in the words and word structure of the target language.

11. Reduction; this technique reduces linguistic elements in translation products to shorten speech. The application of this technique is usually in dubbing and interpreting.

12. Literal translation; translating words from source language based on dictionary meaning. This technique refers to word-to-word translation, and the conveyed meaning might not be proper.

13. Modulation; a translation technique that changes the way the reader thinks both lexically and structurally. There may be different points of view in the results of the translation.

14. Particularization; is translating words or general terms in the source language into specific terms in the translation results.

15. Reduction; is a technique used by reducing linguistic elements or information in the source language without changing the intended meaning.

16. Substitution; is a way of translation that involves paralinguistic elements. This technique converts linguistic elements into intonation or body language.

17. Transposition; is a translation technique carried out to change the adjective location or even change the plural to singular to adjust or match the target language structure. In other words, the translation results in the target language change its grammatical elements.

18. Variation; is a translation by adjusting the product to the language style and social dialect of the target language.

From the descriptions above, these translation techniques are used by the researchers as a basis for examining the utterances found in Disney's Aladdin (2019). Also, this translation technique is used as a theoretical basis to answer the research questions formulated in this research.

\section{Speech Act}

A Speech act is a branch of pragmatics used when communication takes place. It happens because pragmatics examines aspects of speech acts such as the purpose of a speech, the address, and where and how it is spoken (Leech, 1983). The speech act concept comes from two words, namely speech, which means speech and act means action. Then, speech acts are actions that are carried out or delivered through speech as Violeta stated "speech acts are characteristically performed in the utterance of sounds or the making or marks" (Violeta, 2019, p.10). These two things can the form a same meaning as intended by the speaker, but can also be different or even 
the opposite. It gives rise to varieties of speech acts that are influenced by various factors, including the context and intention of the speaker (Siddiq, 2019).

The speech act theory was first presented by Austin, then developed by Searle (1969). Austin (1962) and Tarigan (1990) argued that speech act is an activity in which when speech is spoken and simultaneously followed by an action. The Speech act does not only refer to the content of the communication but also the impact of it. Besides, speech acts involve the behavior of speakers and their interlocutors by analyzing their speech. In other words, communication that occurs between the two parties is an activity containing an intention to be conveyed. It is in line with Chaer (2004), who suggested that in conducting speech acts, the emphasis on the meaning of the actions and its continuity determined by the ability of the speaker's language in dealing with certain situations. Searle (1969) added that communication is the result of an element of language reflected in speech acts.

It concludes that speech act theory is related to the speaker, interlocutor, speech, actions, and meanings contained in the utterance. It relates to communicating messages in the form of speech and actualize it in the form of actions as the effect of speech. Also, the use of speech acts will elude misunderstandings in communication (Fitriyana, 2013).

As proposed by Austin in Bublitz and Norrick (2011) there are three kinds of speech acts. They are:

1. Locution is a type of speech act in which the speaker gives meaning following the actual situation. Locution speech acts are easy to identify because the sentences or expressions already indicate the message communicated without having to pay attention to the application context. Under these conditions, the contents of the spoken utterances provide an impact of action following a clarity of meaning in the uttered sentence. The emerging action is the following with information obtained by the listener. There are three forms of locution speech acts:

a. Declarative, a speech act that comprises a statement as a result of the thoughts of the speaker. It is in the form of both facts and opinions.

b. Interrogative, speech act that aims to ask questions about something to acquire an answer from it.

c. Imperative, a form of speech act that contains an order, whether it is a prohibition or asking someone to do something.

2. Illocution is a speech act that has the opposite meaning with locution. This type of speech act implies more than what the speaker has communicated. There is an implied message from a sentence or phrase that has an impact on the listener's actions. The conveyed meaning is not the intended message by the speaker. This aspect makes illocution more complex. In this situation, the listener must pay attention to the context of the situation when the communication takes place so that the meaning can be understood. Searle (1969) and Cruse (2000) described the forms of illocution speech acts, namely: 
AWEJ for Translation \& Literary Studies Volume, 4 Number 3 August 2020

Teaching Translation through the Implementation of Expressive

Anwar, Haryanti \& Thoyibi

a. Assertive; speech act that is done when communicating truth as what is thought and felt by the speaker. The expressions included in the assertive speech act are proposing, arguing, stating, and reporting.

b. Directive; speech acts that urge the listener to take action based on the utterance. For example, the expressions of commanding, advising, recommending, and ordering.

c. Commissive; is a speech act that impacts the listener's future actions based on the phrase uttered by the speaker. The expressions are in the form of a promise, swear, proposal, threat, and undertake.

d. Expressive; speech act which aims to express the speaker's thoughts and feeling based on the ongoing condition. The expressions can be in the form of expressing apology, lie, gratefulness, complaints, welcoming, condolences, and felicitations.

3. Perlocution is a speech act that aims to influence the listener. When a communication process takes place, speakers directly or indirectly influence the listener (Leech. 1983), such as through persuasion, intimidation, pressure, humiliation, looking for attention, provocation, and amusement. The forms of speech act indicating perlocution are almost similar to those of the locution speech act. Searle in Ronan (2015) categorized speech acts into five types:

a. Representative; focuses on the truth stated by the speaker.

b. Directive; aims to command the listener to do something.

c. Expressive; actions as a result of the involvement of thought and feelings.

d. Commissive; is actions that require the listener to take any action in the future.

e. Declarative; the result of the speech will influence the listener.

\section{Expressive Speech Act}

As stated by Searle (1962), expressive speech acts are speech acts that function to express the results of the speakers' thoughts and feelings towards the ongoing conditions. It occurs through actions shown based on the results of the received stimulus. The types of expressive speech acts divided into apologizing, boasting, thanking, complaining, welcoming, expressing condolences, forgiving, and felicitations.

\section{Apologizing}

Apologizing is the expression of showing sorrow for situations that the speaker is responsible. It also refers to the regret of making a mistake. This expression acquires relief from demands and fines. In different contexts, the expression of apology can also mean asking permission to be able to do something.

\section{Boasting}

Boasting is an expression of self-pride, which also refers to being arrogant and tend to focus more on his/her superiority to appear great and become the spotlight.

\section{Complaining}

People use this speech act to express dissatisfaction. This situation may occur when what happens does not match the expectation.

Arab World English Journal for Translation \& Literary Studies 
AWEJ for Translation \& Literary Studies Volume, 4 Number 3 August 2020

Teaching Translation through the Implementation of Expressive

Anwar, Haryanti \& Thoyibi

\section{Condolence}

An expression to show feelings of sympathy in responses to unpleasant conditions such as illness, death, and misfortune.

\section{Congratulating}

This expression refers to extending congratulations for achievement or victory as a form of appreciation.

\section{Deploring}

Deploring refers to negative emotions on self-perception that cause displeasure due to mistakes that hurt the speaker. It occurs when the expectation does not match reality.

\section{7. $\quad$ Forgiving}

A speech act that conveys forgiveness to another party who has done something that has harmed the speaker. This expression aims to reconcile two parties and to avoid ruining relationships.

\section{8. $\quad$ Thanking}

This expression occurs when the speaker gets benefits from other people and vice versa. It is a form of mutual respect.

\section{Welcoming}

Welcoming is an expression of happiness upon receiving an expected blessing. This expression also refers to the attitude of acceptance with sincerity, for example, in welcoming guests, invitations, and the arrival of family or relatives.

\section{Translation Teaching}

In learning translation, students must be able to master translation to gain broader knowledge and avoid inaccurate understanding. As warwal states, "the purpose of translation is to give knowledge to everyone" (Warwal, 2015, p.126).

Initially, translation was seen as theoretical, as a result of the process of language switching and referring to the ability to interpret the intended message (Lörscher, 1991).

At present, translation is not only the transfer of language but also as communicative learning, in which translation is a means to increase knowledge. Hence, mastering skills in translation is the goal of teaching translation (Li, 2018). Also, Popescu (2013) asserted that by comprehending translation skills, it also means mastering language skills, social, pragmatics, and cultural contexts.

For Duff (1994), applying translation in a language class will affect several situations, such as:

1. There will be sentence patterns and wording, which is influenced by the mother tongue toward translation output in the target language. 
AWEJ for Translation \& Literary Studies Volume, 4 Number 3 August 2020

Teaching Translation through the Implementation of Expressive

Anwar, Haryanti \& Thoyibi

2. Since translation is a natural activity in daily life, it becomes substantial to acquire clarity of meaning that one can gain from the translation process.

3. The art in translating is necessary for conveying ideas that can be recognized by both readers and listeners. Therefore, having a good understanding of both languages is essential to create a quality translation.

4. A translation is an activity that involves the translator directly in using the language as a whole. Thus, translation refers to as a learning tool.

5. Understanding the use of language will increase competence in producing quality translations.

Using translation as a learning object in the classroom will be beneficial for students to understand the use and objectives of translation activities. Since translation does not only refer to language alteration but also the method to maintain the intended meaning (in textual, semantic, and pragmatic meaning). This is in line with Ahdillah, Hartono and Yuliasri (2020) that the real translation does not lie in changing words for word, but needs to consider the context that applies in communication.

Saroukhil, Ghalkhani, and Hashem (2018) emphasized that translation teaching must be well-planned by creating a pleasant and lively atmosphere so that the students become more invested in translation activity to achieve the goal optimally.

There are several aspects to be considered in teaching translation, as follows:

1. Teachers should teach the competencies of both languages and understand linguistic elements (meaning, words, phrases, grammar) and extra-linguistic (fields of science and cultural context).

2. Each language has different cultural values; therefore, translators should have an understanding of the culture in the source language and target language.

3. In analyzing the message of the text in the source language, it is valuable to master the techniques to understand the reading materials so that it can communicate the idea properly.

4. In teaching translation, the techniques as the main aspect in presenting the translation output of target language appropriately.

5. A good translator should master the theory of translation, which includes objectives, processes, strategies, methods, and translation techniques.

To create effective translation learning, Saroukhil, Ghalkhani and Hashem (2018) proposed to link translation learning with other skills in real activities. It will encourage the students to comprehend the use of translation. Besides, designing individual and group activities is highly recommended as participants can discuss ideas related to the results of the translation and gain experience through the process. It can also increase their motivation in learning translation.

There are several researchers study the fields of translation, speech act, and teaching of translation. Nugraha (2019) studied the quality of the translation of expressive speech acts in Stephanie Meyer's Breaking Dawn. The findings showed that there are 19 types expressive speech act of 139 data, including expressions of blame, quip, hope, approve, protest, farewell, mock, greeting, apologize, regret, accuse, curse, grateful, sympathy, grateful, praise, complain, argue, 
and congratulation. And also, Breaking Dawn has good translation quality since the message delivered in entirety. It proved by the number of percentages, $100 \%$ of the readability aspect, $99 \%$ of the acceptance aspect, and 93\% of the accuracy aspect. Wahana, Nababan, and Santosa (2019) analyzed the translation techniques used to translate expressive utterances in Flawless. From 109 utterances, the highest occurrence is an established equivalence technique of $66 \%$ in transferring meaning into the target language. Also, the translator used other techniques such as explicitation, paraphrase, modulation, pure borrowing, implicitation, addition, transposition, adaptation, compensation, reduction, generalization, discursive creation, literal, and particularization. Budiman, Nababan, and Djatmika (2019) have a similar study and result related to translation techniques used in responding to expressive utterance, especially criticizing and apologizing expressive speech acts. Establish equivalence is a translation technique applied the most by the translator. They also confirmed that the selection of translation techniques is chosen by the translator based on the experience, a person's understanding, and ability of the translator.

To apply translation in the field of education, Hartono (2015) proposed teachers to use interactive webs in teaching translation and cease monotonous activity. The examples of interactive web implementation integrated into technology such as blogs, translating search engines, and class sites would enable the accessibility of the learning process. Students' achievement in learning translation could be proven through the improvement of translation quality, In line with Hartono, Giaber (2014) mentioned that the application of translation as a language teaching by EFL teachers in Libya helps students to analyze meaning both explicitly and implicitly, develop their ability in language acquisition, enrich vocabulary, and develop knowledge. Learning speech act becomes more enjoyable by applying movie media. Besides entertaining, movies can increase student interest through moving images, sounds, and effects, so the students are indirectly experiencing the real situation. The research results from Violeta (2019) proved that through the use of films in the teaching of speech acts, students can see and hear directly how to express various feelings and emotions, which make the students understand the material easier. Alonso-Perez \& Sanchez Requena (2018) added that teachers got a positive effect in implementing audio visual translation. Also, teaching translation through audio-visual can enhance students' communication skills and interest in translation. Besides, the way of learning uses audio visual translation can motivate students to develop their translation skills. However, in using audio visual aids, the teacher should have a good understanding in applying it in learning, so that the learning objectives are well achieved.

However, this research can be distinguished from its previous research since the researchers implement audiovisual media (film) to create a new situation in teaching translation as a medium to teach translation techniques to the students.

\section{Research Method}

In conducting the research, the researchers applied descriptive qualitative research. The researchers used library research techniques to collect the data by following these procedures: watching the movie and reading some journals and books to find appropriate theories and data. The source of data is Disney's Aladdin (2019) movie script and translation result. To classify the 
data into expressive expressions, researchers used Searle's (1976) theory. It was applied to divide expressive utterances into several expressions such as apologizing, boasting, condolence, congratulating, deploring, forgiving, lamenting, thanking, and welcoming (Austin, 1962). Also, the researchers used Molina and Albir's (2002) theory to determine translation techniques for speech acts in Aladdin film from the source language into the target language.

\section{Finding}

There were two findings based on the analysis related to the process of teaching translation, by implementing expressive utterances translation techniques as found in Disney's Aladdin (2019) movie script.

Translation Techniques Used in Translating Expressive Utterances of Aladdin 2019 Table 1. Results of translation techniques

\begin{tabular}{|r|r|l|l|}
\hline No. & Category & Frequency & Percentage \\
\hline 1. & Linguistics Compression & 31 & $50.00 \%$ \\
\hline 2. & Established Equivalence & 10 & $16.13 \%$ \\
\hline 3. & Literal Translation & 9 & $14.52 \%$ \\
\hline 4. & Reduction & 4 & $6.45 \%$ \\
\hline 5. & Amplification & 3 & $4.84 \%$ \\
\hline 6. & Modulation & 3 & $4.84 \%$ \\
\hline 7. & Calque & 2 & $3.23 \%$ \\
\hline & Total & & \\
\hline
\end{tabular}

From the total of translation techniques, there are seven kinds of translation techniques of expressive utterances used by the translator of Disney's Aladdin (2019), such as linguistics compression, established equivalence, literal translation, reduction, amplification, modulation, and calque. Linguistics compression technique becomes most commonly used by $50.00 \%$, followed by established equivalence (16.13\%), literal translation (14.52\%), reduction (6.45\%), amplification $(4.84 \%)$, modulation $(4.84 \%)$ and calque $(3.23 \%)$.

The techniques of translation used in translating expressive utterances from Disney's Aladdin (2019) script are as follows:

\section{Linguistics Compression}

This technique is a reduction of linguistic elements in translation product which is intended to shorten speech. The use of this technique is usually in dubbing and interpreting. 


\section{Datum 1}

SL : "Why are you repeating everything I say?"

TL : "Kenapa kau ulangi ucapanku?"

Datum 1 used linguistics compression to translate complaining expression. This technique tended to unify linguistics elements in the source language, which resulted in shorter translation in the target language. The utterance "Why are you repeating everything I say?" could be reflected in the situation in the target language "Kenapa kau ulangi ucapanku?" Although the word "everything" was not translated, the message of the expression was acceptable in the target language.

\section{Established Equivalence}

This translation technique is to by finding equivalent words and terms that are commonly used daily in the target language.

\section{Datum 2}

SL : "How can I ever thank you?"

TL : "Bagaimana caraku berterima kasih?"

The output translation of this technique applied familiar terms in the target language to enable the listeners to understand the message more easily. The utterance "can I ever" was translated into the common word "caraku" in the target language.

\section{Literal Translation}

Literal translation means translating words from source language based on dictionary meaning. This technique refers to the word translation, while the conveyed meaning might not be proper.

\section{Datum 3}

SL : "Second? Only second?"

TL : "Kedua? Hanya kedua?"

Literal translation technique was found in datum 3. The words were translated based on dictionary meaning. The word "second" was translated into "kedua" and "only" into "hanya". It showed that literal techniques used word by word translation.

\section{Reduction}

This technique is used by reducing linguistic elements or information in the source language without changing the intended meaning.

\section{Datum 4}

SL : : "In the 1,000-year history of our kingdom. I have been preparing for this my whole life. I have read."

TL : "Selama 1.000 tahun kerajaan berdiri. Kusiapkan ini sejak lama. Aku sudah baca."

Reduction means to shorten the word of the original text without any changing of the intended meaning. The word "history", "our", and "my whole life" were not translated in the 
AWEJ for Translation \& Literary Studies Volume, 4 Number 3 August 2020

Teaching Translation through the Implementation of Expressive

Anwar, Haryanti \& Thoyibi

target language. However, the translation output in the target language could deliver the contents without reducing its message.

\section{Amplification}

This technique refers to adding information in the target language that aims to make it easier for readers to grasp the meaning.

\section{Datum 5}

SL : "You steal from my brother."

TL : "Kau curi dagangan saudaraku."

This datum had been translated using the amplification technique due to the addition of words in the target language. In the target language, the word "dagangan" was additional to provide clarity to the reader.

\section{Modulation}

This technique changes the way the reader thinks, both lexically and structurally. Different points of view will be seen in the results of the translation.

\section{Datum 6}

SL : "Books? But you cannot read experience. Inexperience is dangerous."

TL : "Buku? Pengalaman tak didapat lewat membaca. Kurang pengalaman itu bahaya."

In this datum, the translation is done by using a modulation technique to convey the ideas. The modulation technique referred to shifting others' viewpoints. It occurred both lexically and structurally. The utterance "But you cannot read experience" had been changed into a different structure "Pengalaman tak didapat lewat membaca".

\section{Calque}

The translation is based on the meaning of the word and its structure. The transfer of language from the original text into the target language takes place literally.

\section{Datum 7}

SL : "I apologize"

TL : "Maafkan aku"

Datum 7 applied a calque technique in the expression of apology. Calque technique means translating foreign words or phrases into the target language by adjusting the structure of the target language. Therefore, the utterance "I apologize" was translated literally and based on its structure.

\section{The Implementation of Translation Techniques in Translation Teaching}

There are several steps to teach translation techniques of expressive utterances through Disney's Aladdin (2019):

1. At first, the teachers explained the core of translation theories, which included its techniques and theory of expressive utterances. 
AWEJ for Translation \& Literary Studies Volume, 4 Number 3 August 2020

Teaching Translation through the Implementation of Expressive

Anwar, Haryanti \& Thoyibi

2. Then, to ensure that the students have clear comprehension, the teachers showed a short movie with the script and let them explore their understanding related to translation techniques of expressive utterances by determining translation techniques in each expressive utterances used by the translator. Through movie playback, the students were able to feel the social context and culture of the movie that would facilitate them to do the translation.

3. After specifying the techniques of translation, the students and the teachers clarified the correct answers.

4. For the main activity, the teachers asked students to watch Disney's Aladdin (2019) by paying attention to the cultural context in the movie. Also, they have to classify expressive utterances and their translation techniques individually.

5. During the translation process, the teachers asked the students whether or not they encountered any obstacles. Since the teachers observed every group, they may find both appropriate and inappropriate analysis of the students. Therefore, the teachers had to make sure the students understand the theory and its implementation well.

6. After the analyzing process had finished, the next step was allowing the students to work in a group. Each group consisted of four students. The students might switch their works to other friends in a group and gave feedback. Enabling discussion within groups would give positive impacts for the students to improve their skills in translation as they would understand their weaknesses and strength in doing the translation. Therefore, they would try to improve their limitation and use their strength to practice more.

7. Lastly, the teachers assessed the translation results to measure the students' achievement and discussed the practice of translations techniques application. At the end of the learning process, the teachers encouraged the students to keep practicing translation to produce better translation quality.

\section{Discussion}

Regarding the outcomes of the study, from the 62 expressive utterances found, there were seven types of expressive speech translation techniques applied by the translators in Disney's Aladdin (2019) based on Molina and Albir (2002) theory. They are amplification, calque, established equivalents, linguistic compression, literal translation, modulation, and reduction. The translation technique which is used the most is linguistic compression technique. In contrast to previous studies (Aresta, et al. 2019; Wahana, et al. 2019) that in translating expressive expressions, the translator implemented the establish equivalence technique. In Disney's Aladdin (2019), expressive expressions are translated more through linguistic compression techniques because this technique emphasizes the delivery of the core points of utterances from the original text to the target text to keep message which is easily understood by readers. With different results, it does not mean that the technique chosen by the translator is incorrect. However, every translator has a different background, style and ability to produce translations as proposed by Budiman, Nababan and Djatmika (2019).

The application of audiovisual films in teaching translation techniques is indeed able to build up students' enthusiasm, motivation, and ability in translation. Also, this creates a more 
pleasant atmosphere for students, which will make students enjoy learning translation, as has been investigated by Alonso-Perez \& Sanchez Requena (2018). In addition to presenting a more lively atmosphere, the application of audiovisual in the form of films in teaching translation can make it easier for students to obtain material through moving images, sounds, gestures, intonations, which are included in features in the film. This has a positive impact on student mastery in translation, as supported by Violeta (2019).

\section{Conclusion}

After conducting the research through a descriptive qualitative method, the researchers found 62 examples of expressive utterances, which translated using seven translation techniques, such as linguistics compression, established equivalence, literal translation, reduction, amplification, modulation, and calque. Furthermore, the findings of this research can be used as a material for teaching translation. As for how to overcome students' belief about translation learning, which is considered boring and tiring, the teacher can use audio-visual aid in the form of films. The application is by explaining translation theories and its techniques, observing the movie, analyzing the translation output by the translator, and conducting assessments to measure the students' achievement. Consequently, the implementation of translation techniques in translation teaching increased students' sensitivity of language, gained broader insights about cultures, and enabled the students to produce better translation quality. In conclusion, teaching translation techniques becomes significant in developing students' critical thinking to present ideas into target language appropriately.

\section{About the Authors:}

Farrah Zakiyah Anwar is an English teacher in SMA Muhammadiyah (Plus) Salatiga. She received a bachelor's degree in English Department from the Institute for Islamic Studies (IAIN) Salatiga. She continued her postgraduate on English education at the Muhammadiyah University of Surakarta. Her research interests are language teaching, translation studies, and pragmatics. She has attended many seminars, workshops, and training in English teaching and learning. https://orcid.org/0000-0002-2775-9768

Dwi Haryanti is an English lecturer at the Muhammadiyah University of Surakarta University's Department of English Education. She received a bachelor's degree in Linguistics from Diponegoro University, the Master's degree in applied linguistics (translation) from Sebelas Maret University of Surakarta, and Doctoral degree from Sebelas Maret University of Surakarta. She is interested in language teaching and translation. She delivered her papers at many international conference and seminar. https://orcid.org/0000-0003-4150-8727

Muhammad Thoyibi is an English lecturer and Head of basic science and language development at the Muhammadiyah University of Surakarta. He received a bachelor's degree in English Literature from Sebelas Maret University of Surakarta, the Master's degree in American Studies from Gadjah Mada University of Yogyakarta, and Doctoral degree from Gadjah Mada University of Yogyakarta. He is interested in language teaching and translation. He delivered his papers at many international conference and seminar. https://orcid.org/0000-0001-6865-0454 


\section{References}

Ahdillah, M.Z.I, Hartono, R. \& Yuliasri, I. (2020). English - Indonesian Translation of Idiomatic Expressions Found in The Adventure of Tom Sawyer: Strategies Used and Resulted Equivalence. English Education Journal., 10(4), 482-494.

Agustuno, G. (2011). An Analysis of Translation TechniquesandTranslation Quality of Flight Attendant Manual. Sebelas Maret University Surakarta. Indonesia.

Akhiroh, Ninuk Sholikhah. (2013). The Influence of Translation Technique on The Quality of The Translation of International News in Seputar Indonesia Daily. Semarang State University. Indonesia.

Alonso-Perez, R \& Sanchez Requena, A. (2018). Teaching foreign languages through audiovisual translation resources: teachers' perspectives. Applied Language Learning, 28(2), 1-24.

Aresta, R., Nababan, M.R., Djatmika. (2018). The Influence of Translation Techniques on the Accuracy and Acceptability of Translated Utterances that Flout the Maxim of Quality. Journal of Humaniora, 30(2). doi.org/102216/jh.v29i3.33645

Austin, J. L. (1962). How do to Things with Words. Oxford: The Clarendon Press.

Bai, Zhihong. (2018). On Translation Strategies of English Movie Titles. Journal of Language Teaching and Research, 9(1), 119-124. DOI: http://dx.doi.org/10.17507/jltr.0901.15

Bassnett-McGuire, Susan. (1980). Translation Studies. London and New York: Methuen.

Bublitz, W., \& Norrick, N. R. (Eds.). (2011). Foundations of pragmatics. Berlin: De Gruyter Mouton.

Budiman, R. A., Nababan, M. R., \& Djamika. (2019). Translation Technique of Utterance which Accommodate Responses f Expressive Critizing and Apologizing Speech Acts. Jurnal

Ilmiah Ilmu- Ilmu Humaniora, 18(1), 1-11. DOI: https://doi.org/10.24036/humanus.v18i1.102391

Catford, J.C. (1978). A Linguistic Theory of Translation. Oxford: Oxford University Press.

Chaer, A. (2004). Sosiolinguistik: Perkenalan Awal. Jakarta: Rineka Cipta.

Cruse, A. D. (2000). Meaning in Language, an Introduction to Semantics. Oxford: Oxford University Press.

Duff, A. (1994). Translation. London: Oxford University Press.

Fitriana, I. (2013). Translation Analysis of Directive Speech Acts in "Eat Pray Love" Novel and Its Translation into Indonesian. UNS Journal of Language Studies, 2(2), 13-28.

Giaber, M. J. (2014). Use of Translation in the Classroom by EFL Teachers in Libya. Arab World English Journal, (3), 27-40.

Hartono, R. (2012). Teori Penerjemahan (Handbook for Translators). Cipta Prima Nusantara Semarang

Hartono, R. (2015). Teaching Translation through the Interactive Web. LANGUAGE CIRCLE Journal of Language and Literature, 9(2), 129-140. DOI: https://doi.org/10.15294/lc.v9i2.3703

Kusumarasdyati, K (2004). Listening, Viewing and imagination: Movies in EFL Classes. Paper presented at the 2nd International Conference on Imagination and Education. Vancouver, Canada.

Arab World English Journal for Translation \& Literary Studies 
AWEJ for Translation \& Literary Studies Volume, 4 Number 3 August 2020

Teaching Translation through the Implementation of Expressive

Anwar, Haryanti \& Thoyibi

Larson, M.L. (1984). Meaning Based Translation: A Guide to Cross-Language Equivalence. Lanham \& London: University Press of America.

Leech, G. (1983). Principles of pragmatics. London: Longman.

Li, X. (2018). International Research on Translation Teaching: A Review (2008-2017). Theory and Practice in Language Studies, 8(6), 656-664. DOI: http://dx.doi.org/10.17507/tpls.0806.16

Lörscher, W. (1991). Translation performance, Translation process, Translation strategies: A Psycholinguistic Investigation. Tubingen: Gunter Narr.

Luo, J. (2004). Using DVD Films to Enhance College Freshmen's English Listening Comprehension and Motivation, Unpublished master thesis. National Tsing Hua University, Hsinchu. Taiwan.

Molina, L., \& Albir, A.H. (2002). Translation Techniques Revisited: A Dynamic and Functionlist Approach. Meta: Translators' Journal, XLVII(4), 498 - 512. DOI: https://doi.org/10.7202/008033ar.

Muntane, B.J., Faraco, S.S. (2016). Watching Subtitled Films Can Help Learning Foreign Languages. PLoS ONE, 11(6), Article e0158409. https://doi.org/10.1371/journal.pone.0158409

Newmark, P. (1988). A textbook of Translation. London and New York: Prentice HaH International vUIO Ltd.

Nida, E.A., \& Taber. C. R. (1974). The Theory and Practice of Translation. Leiden: E.J. Brill.

Nugraha, H. (2019). Kualitas Terjemahan Tindak Tutur Ekspresif dalam Novel Breaking Down. Jurnal al-Tsaqafa, 16(1), 124-134.

Pinchuck, Isadore. (1977). Scientific and Technical Translation. London: Andre Deutsch.

Popescu, T. (2013). Developing English linguistics students' translation competence through the language learning process. Procedia-Social and Behavioral Sciences, 93, 1075-1079. DOI: 10.1016/j.sbspro.2013.09.333

Ronan, P. (2015). Categorizing expressive speech acts in the pragmatically annotated SPICE Ireland corpus. ICAME Journal, 39(1), 25-45. https://doi.org/10.1515/icame-2015-0002

Saroukhil, A. M., Ghalkhani, O., \& Hashem, (2018). A Critical Review of Translation: A Look Forward. International Journal of Education \& Literacy Studies, 6(2), 101-110. DOI: http://dx.doi.org/10.7575/aiac.ijels.v.6n.2p.101

Searle, J. R. (1969). Speech acts: An essay in the philosophy of language. Cambridge: Cambridge University Press.

Searle, J. R. (1976). A classification of illocutionary acts. Language in Society, 5(01), 1-23.

Siddiq, M. (2019). Tindak Tutur dan Pemerolehan Pragmatik pada Anak Usia Dini. Jurnal Kredo.

2 (2), 268-290.

Sommer, P. (2001). Using Film in the English Classroom: Why and How. Journal of Adolescent and Adult Literacy, 44(5), 485-487.

Steiner, E. (2004). Translated texts: properties, variants, evaluations. Frankurt: Peter Lang

Tarigan, H.G. (1990). Pengajaran Pragmatik. Bandung : Angkasa Bandung.

Warwal, S. S. (2015). Translation Process and Problem of Translation in World Classics. An International Multidisciplinary Research e-Journal, 1(1), 125-133.

Arab World English Journal for Translation \& Literary Studies

ISSN: 2550-1542 | www.awej-tls.org 
AWEJ for Translation \& Literary Studies Volume, 4 Number 3 August 2020

Teaching Translation through the Implementation of Expressive

Anwar, Haryanti \& Thoyibi

Violeta, R. (2019). Speech Act Analysis of The Main Character in Maleficent Movie Script [Unpublished bachelor's thesis]. University of Islamic State Raden Intan Lampung.

Wahana, D., Nababan, M.R., \& Santosa, R. (2019). Translation Techniques of Expressive Speech Acts on Anger Speech Events in Flawless. International Journal of Expressive Speech of Linguistics, Literature and Translation, 2(5), 118-131. DOI: 10.32996/ijllt.2019.2.5.144

William, R. (1977). Keyword: A Vocabulary of Culture and Society. New York: Oxford University Press.

Wuryantoro, A. (2017). Problems in Learning Translation. Linguista, 1(1), 30-35.

Yakup, D. (2016). The Issues on Translation of Film Titles And Publicistic Headlines. Alatoo Academic Studies, (1), 2-56. Retrived from

https://www.researchgate.net/publication/313315503

Arab World English Journal for Translation \& Literary Studies

ISSN: 2550-1542 | www.awej-tls.org 